\title{
Sources and select bibliography
}

\section{Primary sources, unpublished}

\section{Archives}

AB: $\quad$ Archive Bronbeek, Arnhem. (Documents courtesy of Leo van Bergen.)

AS: $\quad$ National Archive, The Hague, Algemene secretarie Nederlandsche West-Indische bezittingen in Suriname 1830-1847. Inv. nr. 1.05.08.02.

BP: $\quad$ Archive Bisdom of Paramaribo.

CE: $\quad$ National Archive, The Hague, Handelingen en Bijlagen van de (Koloniale) Staten van Suriname. Inv. nr. 2.10.44.

CRO: $\quad$ National Archives, Kew. Colonial Record Office

DS: $\quad$ National Archive, Paramaribo, Districtscommissariaat Saramacca 1897-1955. Inv. nr. 1.24.01.

DTB: $\quad$ National Archive, The Hague, Doop-, trouw- en begraafboeken van Suriname. Inv. nr. 1.05.11.16.

GS: $\quad$ National Archive, Paramaribo, Gouvernementssecretarie Suriname 1829-1954. Inv. nr. 1.01.01.

GS II: National Archive, The Hague, Gouverneur van Suriname 1885-1951. Inv. nr. 2.10.18.

LN: $\quad$ League of Nations Leprosy Committee, League of Nations Room, United Nations, Geneva, 'Suriname.' (Documents courtesy of Jo Robertson.)

NA 2WC: National Archive, The Hague, Tweede West-Indische Compagnie Archive. Inv. nr. 1.05.01.02.

ZZ: $\quad$ Utrecht Historical Archive, Utrecht, Zeister Zendingsgenootschap. 


\section{Primary sources available online}

CR: $\quad$ Colonial Reports. Verslag van het beheer en den staat der Koloniën (1849-1865); Koloniaal Verslag (1866-1923); Verslag van bestuur en staat van Suriname (1924-1930); Surinaamsch Verslag (1931-1950): www.statengeneraaldigitaal.nl/.

SA: $\quad$ Surinamese almanacs: www.dbnl.org/.

SG: $\quad$ Proceedings of the Dutch Parliament. Handelingen StatenGeneraal: www.statengeneraaldigitaal.nl/.

SN: $\quad$ Surinamese newspapers: www.delpher.nl/nl/kranten/.

\section{Primary sources, printed}

\section{Journals}

BB: $\quad$ Brieven uit Bethesda (Paramaribo: Protestantsche Melaatschen-inrichting Bethesda, 1934-1938).

GB: $\quad$ Gouvernementsblad van de Kolonie Suriname (Paramaribo: Gouvernement Suriname, 1816-1950).

GV: De Godsdienstvriend (Amsterdam: A. Schievenbus, 1818-1869).

SB: $\quad$ Stemmen uit Bethesda (Amsterdam: De Bussy, 1900-1951).

\section{Books and articles}

Beek, J. P. ter, 'Dissertatio medico-inauguralis de elephantiasi Surinamensi' (MD thesis, University of Leiden, 1841).

Benjamins, H. D., 'Treef', in H. D.Benjamins and J. F. Snelleman (eds.), Encyclopaedie van Nederlandsch West-Indië ('s-Gravenhage: Martinus Nijhoff, 1914-1917), pp. 685-7.

Benjamins, H. D., 'Treef en lepra in Suriname', West-Indische Gids 11 (1930), pp. $187-218$.

Benjamins, H. D., and J. F. Snelleman (eds.), Encyclopaedie van Nederlandsch West-Indië ('s-Gravenhage: Martinus Nijhoff, 1914-1917).

Benoit, P. J., Reis door Suriname. Beschrijving van de Nederlandse bezittingen in Guyana (Zutphen: De Walburg Pers, 1980).

Bethesda. Een liefdewerk der protestanten in Suriname (Paramaribo: Protestantsche Vereeniging ter verpleging van Lepralijders in de Kolonie Suriname, 1902). 
Blankensteijn, M. van, Suriname (Rotterdam: Nigh and Van Ditmar, 1923). Blom, A., Verhandeling over de landbouw in de colonie Suriname (Amsterdam: J.W. Smit, 1787).

Bonne, C., 'De maatschappelijke beteekenis der Surinaamsche ziekten', West-Indische Gids 1 (1919), pp. 291-300.

Bosman, W., Nauwkeurige beschrijving van de Guinese Goud-, Tand-en Slavenkust. (Amsterdam: Isaac Stokmans, 1709).

Bosser, A., Beknopte geschiedenis der katholieke missie in Suriname (Gulpen: M. Alberts, 1884).

Broes van Dort, T., 'Een en ander over de lepra in Nederland en zijne koloniën', Nederlandsch Tijdschrift voor Geneeskunde 41 (1897), pp. 292-6, 384-91, 407-21, 650-1.

Broes van Dort, T., 'De internationale lepra-conferentie te Berlijn (11-16 Oct. 1897)', Nederlandsch Tijdschrift voor Geneeskunde 41 (1897), pp. 747-71, 810-15, 893-7, 937-42, 978-84.

Brons, J. C., Het rijksdeel Suriname (Haarlem: Bohn, 1952).

Büchner, W. F., Geneeskundig handboek voor beginnende kunstoefenaren (Amsterdam: H. J. Berntrop, 1839).

Canstatt, C., Handbuch der medicinischen Klinik, 3rd rev. ed., vol. 2 (Erlangen: Ferdinand Enke, 1855), pp. 1-15.

Carsten, B., 'Over de verspreidingswijze van lepra', Nederlands Tijdschrift voor Geneeskunde 11 (1867), pp. 481-5.

Cool, P., 'Regeeringsmaatregelen ter bestrijding der lepra in Suriname en Aruba', Nederlandsch Tijdschrift voor Geneeskunde 71 (1927), pp. 2453-6.

Coster, A. M., 'De boschnegers in de kolonie Suriname. Hun leven, zeden, en gewoonten', Bijdragen tot de Taal-, Land-en Volkenkunde 13 (1866), pp. 1-37.

Debien, G., 'Le marronage aux Antilles françaises au XVIIIe siècle', Caribbean Studies 6 (1966), pp. 3-43.

Deutschbein, L. L. A., 'De noma infantum' (MD thesis, University of Halle 1840).

Deutschbein, L. L. A., 'Report', Tijdschrift voor de Wis- en Natuurkundige Wetenschappen 5 (1852), pp. 100-5.

Dissel, J. A. van, 'Iets over de godsdienst der Javanen', Tijdschrift voor Nederlandsch-Indië 3rd series, 3 (1869), pp. 375-85.

Dresen, H. B., Gouden jubilé van de R. K. leprozerie Sint Gerarus Majella Stichting (Paramaribo: Sint Gerardus Majella Stichting, 1945).

Drognat Landré, C. L., De besmettelijkheid der lepra arabum, bewezen door de geschiedenis dezer ziekte in Suriname (Utrecht: J. L. Beijers, 1867).

Drognat Landré, C. L., De la contagion seule cause de la propagation de la leprè (Paris: Guillaume Baillière, 1869). 
Essed, W. F. R., 'Eenige opmerkingen naar aanleiding van de artikelen over treef en lepra in dit tijdschrift verschenen', West-Indische Gids 12 (1931), pp. 257-67.

Fermin, P., Traité des maladies les plus frequenter à Surinam, et des remedes les plus propres à les guérir (Maastricht: Jacques Lekens, 1764).

Fermin, P., Nieuwe algemeene beschryving van de colonie van Suriname (Harlingen: Volkert van der Plaats, 1770).

Flu, P. C., De filaria-ziekte in Suriname (The Hague: Algemeene Landsdrukkerij, 1911).

Flu, P. C., 'Het een en ander over de besmetting met lepra', Stemmen uit Bethesda 29 (1924), pp. 56-7.

Flu, P. C., Verslag van een studiereis naar Suriname (Nederlandsch Guyana.) Sept. 1927 - Dec. 1927 (Utrecht: Kemink, 1928).

Fock, L. C. E. E., Natuur-en geneeskundig etymologisch woordenboek (n.p.: J. Noorduyn, 1855).

Friedman, S., Nederlandsch Oost-en West-Indië, volgens de nieuwste inrigting, met betrekking tot aardrijkskunde, statistieken, voortbrengselen, luchtgesteldheid, en vooral tot den gezondheidstoestand (Amsterdam: J. C. A. Sülpke, 1861).

Fuchs, C. H., Die krankhaften Veränderungen der Haut und ihrer Anhänge (Göttingen: Dietrichsen Buchhandlung, 1840).

Gallandat, D. H., Noodige onderrigtingen voor de slaafhandelaren (Middelburg: Pieter Gilissen, 1769).

Gedenkboek van het koloniaal-militair invalidenhuis Bronbeek (Amsterdam: P. Gouda Quint, 1881).

Geschiedenis der kolonie van Suriname... Door een Gezelschap van geleerde joodsche mannen aldaar, vol. 2 (Amsterdam: Allart \& Van der Plaats, 1791)

Gypser, K.-H. (ed.), Herings Medizinische Schriften, 3 vols. (Göttingen: Ulruch Burgdorf, 1988).

Hartsinck, J. J., Beschrijving van Guiana of de Wilde Kust, in Zuid-Amerika, 2 vols. (Amsterdam: Gerrit Tielenburg, 1770).

Hasewinkel, W., 'Jaarverslag van het Gesticht Bethesda, Suriname', Berichten uit de Heidenwereld 19 (1923), pp. 37-42.

Hasselaar, A. van, Beschrijving der in de kolonie Suriname voorkomende elephantiasis en lepra (melaatschheid) (Amsterdam: S. de Greber, 1835).

Herskovits, M. J., and F. S. Herskovits, Suriname Folk-lore (New York: Columbia University Press, 1936).

Hille, J., 'Ueber die Elephantiasis; nach eigenen Beobachtungen in WestIndien', Wochenschrift für die gesammte Heilkunde (1841), pp. 433-42.

Hillis, J. D., Leprosy in British Guiana: An account of West Indian leprosy (London: J. A. Churchill, 1881). 
Houttuyn, M., Handleiding tot de plant- en kruidkunde, vol. 3 (Amsterdam: Lodewijk van Es, n.d.).

Huet, G. D. H., 'Een geval van lepra arabum. Lijkopening', Nederlandsch Tijdschrift voor Geneeskunde 12 (1868), pp. 113-20.

Jharap, E., Vertrouwen in eigen kunnen (The Hague: Amrit, 2007).

Jonge, B. C. de, Herinneringen (Groningen: Wolters-Noordhoff, 1968)

Kappler, A., Surinam, sein Land, seine Natur, Bevölkerung und seine KulturVerhältnisse (Stuttgart: J. G. Cotta, 1887).

Käyser, J. D., 'Beschouwingen naar aanleiding van het Verslag van de IIIde Internationale Lepraconferentie, gehouden te Straatsburg van 28-29 Juli 1923', Geneeskundig Tijdschrift voor Nederlandsch-Indië 65 (1925), pp. 716-50.

Kuhn, F. A., Beschouwing van den toestand der Surinaamsche plantagieslaven. Eene oeconomisch-geneeskundige bijdrage tot verbetering deszelven (Amsterdam: C. G. Sulpke, 1828).

Kuhn, F. A., 'Over de elephantiasis te Suriname', Hippocrates 7 (1828), pp. 12-28.

Kuijs, A. P., and G. J. Rijnders, Waarneming eener Elephantiasis aan het linkerbeen (Amsterdam: Ten Brink \& De Vries, 1820).

Lampe, P. H. J., 'Enkele opmerkingen over den sociaal-hygienischen toestand en de geneeskundige verzorging van Suriname', West-Indische Gids 8 (1927), pp. 249-76.

Lampe, P. H. J., 'Sociaal-hygiënische beschouwingen' (Kon. Vereeniging Koloniaal Instituut, Mededeeling no. XXIII, 1927).

Lampe, P. H. J., 'Het Surinaamsche treefgeloof. Een volksgeloof betreffende het ontstaan van de melaatschheid', West-Indische Gids 10 (1929), pp. 545-68.

Lampe, P. H. J., and R. Boenjamin, 'Social intercourse with lepers and the subsequent development of manifest leprosy', Documenta Neerlandica et Indonesica de morbis tropicis 1 (1949), pp. 289-346.

Lampe, P. H. J., and C. Simons, 'Lepra in Suriname', Nederlandsch Tijdschrift voor Geneeskunde 73 (1929), pp. 4903-15.

Lampe, R., 'Ik werd militair' (n.p., 1947).

Landré, C., 'Bijdragen tot de kennis der ziekten van de negers in de kolonie Suriname', Nieuw Praktisch Tijdschrift voor Geneeskunde in al haren omvang, 31 (Nieuwe reeks 4, 1852), pp. 496-7.

Landré, C. H., 'Naschrift bij P. Duchassaing, Over de Elephantiasis Arabum in West-Indië', West-Indië. Bijdragen tot de bevordering van de kennis der Nederlandsch West-Indische kolonien, 2 (1858), pp. 222-33.

Landré, C., 'Sur la contagion de la leprè', in F. J. van Leent A. A. G. Guye, de Perrot, and J. Zeeman (eds.), Congrès international de medicine des colonies, Amsterdam, Septembre 1883 (Amsterdam: F. van Rossen, 1884), pp. 277-9. 
Landré, C., Over de oorzaken der verbreiding van de lepra. Een waarschuwend woord hoofdzakelijk gericht tot de bewoners van Suriname (The Hague: Martinus Nijhoff, 1889).

Langen, C. D. de, and A. Lichtenstein, Leerboek der tropische geneeskunde, 2nd rev. ed. (Weltevreden: G. Kolff, 1928).

Leent, F. J. van, 'Review of Landré, Besmettelijkheid', Geneeskundig Tijdschrift voor de Zeemagt 7 (1869), pp. 63-75.

Lemmens, A. F., Bijdragen tot de Kennis van de Kolonie Suriname. Tijdvak 18161822 (Geografisch en Planologisch Instituut VU Amsterdam, 1982).

Lens, T., 'Lepra in Suriname', Elsevier's Geillustreerd Maandschrift 10 (1895), pp. 521-52.

Lichtveld, L., 'Op zoek naar de spin', West-Indische Gids 12 (1931), pp. 209-30.

Lier, W. F. van, 'Aanteekeningen over het geestelijk leven en de samenleving der Djoeka's (Aukaner Boschnegers) in Suriname', Bijdragen tot de Taal-, land-en Volkenkunde 99 (1940) pp. 130-294, on pp. 273-6.

Ludwig, J. F., Neueste Nachrichten von Surinam (Jena: Akademischen Buchhandlung, 1789).

Maijer, L. T., De Javaan als doekoen. Een ethnografische bijdrage (Weltevreden: G. Wolff, 1918).

Manson, P., Tropical Diseases: A Manual of the Diseases of Warm Climates, rev. ed. (London: Cassell, 1903).

May, T., 'De lepra, haar voorkomen, verspreiding en bestrijding, in 't bijzonder in Suriname', I, West-Indische Gids 8 (1927), pp. 547-56, II West-Indische Gids 9 (1928), pp. 17-31.

'Mededeelingen nopens de lepra in onze West-Indische bezittingen', Nieuw Praktisch Tijdschrift voor de Geneeskunde 28, Nieuwe reeks 1 (1849), pp. 546-68, 761-70.

Miitheilungen und Verhandlungen der internationalen wissenschaftlichen Lepra-Conferenz zu Berlin, 3 vols. (Berlin: August Hirschwald, 1897).

Oudermeulen, B. van der. 'Iets tot voordeel der deelgenooten van de OostIndische Compagnie en tot nut van ieder ingezetenen van dit gemenebest kan strekken', in D. van Hogendorp (ed.), Stukken, raakende den tegenwoordige toestand der Bataafsche bezittingen in Oost-Indië en de handel op derzelve (The Hague: J. C. Leeuwesteyn, 1801), pp. 327-38, on pp. 327-8.

Panhuys, L. C. van, 'About the "trefe" superstition in the colony of Surinam', Janus 28 (1924).

Panhuys, L. C. van, 'Zeer aanmoedigende uitkomsten van lepra-behandeling', West-Indische Gids 10 (1929), pp. 89-92.

Panhuys, L. C. van, 'De opoffering van een R. K. priester in Suriname', WestIndische Gids 18 (1937), pp. 201-6. 
Penard, F. P., and A. Penard, 'Surinaamsch bijgeloof'. Iets over Winti en andere natuurbegrippen', Bijdragen tot de Taal-, Land-en Volkenkunde van Nederlandsch-Indië 67 (1913), pp. 157-89.

Peschuël-Loesche, P., Volkskunde von Loango (Stuttgart: Stecker and Schröder, 1907).

Plante Fébure, J. M., West-Indië in het parlement 1897-1917, Bijdrage tot Nederland's koloniaal-politieke geschiedenis ('s-Gravenhage, Martinus Nijhoff, 1918).

Reddingius, R. A., 'Review of Landré, Oorzaken', Nederlandsch tijdschrift voor Geneeskunde 33 (1889), p. 586.

Reijnders, B. J. C., 'Het werk van de Evangelische Broedergemeente in Suriname', West-Indische Gids 28 (1947), pp. 300-11.

'Report Commissie van Geneeskundig Onderzoek en Toevoorzigt', Nieuw Praktisch Tijdschrift voor de Geneeskunde in al haren omvang 1 (1849), pp. 554-65.

Rodschied, E. K., Medizinische und Chirurgische Bemerkungen über das Klima, die Lebensweise und Krankheiten der Einwohner der Holländischen Kolonie Rio Essequibo (Frankfurt: Jaegerschen Buchhandlung, 1796).

Rogers, L., Happy Toil: Fifty-five Years of Tropical Medicine (London: Frederick Muller, 1950).

Rolander, D., 'Journal', in L. Hansen, D. Goodall, and J. Dobreff (eds.), The Linnaeus Apostles: Global Science and Adventure, vol. 3, bd. 3 (London: IK Foundation, 2008), pp. 1217-564.

Sanders, C. H., De melaatschheid (Groningen: R. J. Schierbeek, 1867).

Schaick, C. van, De manja, Familietafereel uit het Surinaamsche volksleven (Arnhem: D. A. Thieme, 1866).

Schilling, G. W., 'Dissertatio medica inauguralis de lepra' (MD thesis, University of Utrecht, 1769).

Schilling, G. W., Diatribe de morbo in Europa pene ignoto, quem America vocant Jaws (Utrecht: J. C. ten Bosch, 1770).

Schilling, G. W., Geneeskundige verhandeling van eene in Europa byna onbekende ziekte, bij de Amerikanen JAWS genoemd (Middelburg: Christiaan Bohemer, 1770).

Schilling, G. W., Verhandeling over de melaatsheid (Utrecht: J. C. ten Bosch, 1771).

Schilling, G. W., 'Animadversiones in Ouseelianam et additamenta ad suam de lepra dissertationem', in J. D. Hahn (ed.), De lepra commentationes (Leiden: Abr. van Paddenburg, 1778), pp. 119-203.

Schneevoogt, V., 'Verslag op het rapport van den heer Ooijkaas, omtrent het lepreuzen etablissement Batavia, in de kolonie Suriname', Verslagen en Mededeelingen der Koninklijke Akademie van Wetenschappen 2 (1854), pp.381-8. 
Schönfeld. K. D., 'Verhandeling over de lepra in 't algemeen, en de elephantiasis tuberculosa in 't bijzonder' (MD-thesis, University Groningen 1857).

Schuitemaker, F. P., De lepra en de gouvernementsleproserie in Suriname (Amsterdam: J. H. de Bussy, 1915).

Schuitemaker, F. P., 'De Lepra-bestrijding met Hydnocarpus-olie is geen neiuwe Engelsche vinding', Suriname 12 April 1928; reprinted in WestIndische Gids 10 (1929), pp. 93-6.

Schuitemaker, F. P., 'Bezoek aan St. Louis, het leprozeneiland in de Marowyne; melaatschen etablissement van de Fransche strafkolonie St Laurent, Fransch-Guyana', De West-Indische Gids 11 (1930), pp. 177-86.

Schweigman, F., Twee Missionarissen onder de Melaatschen en Indianen van Suriname (Roermond: J. J. Remen, 1894), pp. 1-173.

Schweigman, F., Aan de leden van het Hofbauer-liefdewerk: Pater Donders (Amsterdam: Borg, 1900).

Simons, R. D. G. P., 'De maatschappelijke beteekenis der Surinaamsche ziekten', West-Indische Gids 14 (1933), pp. 429-39.

Simons, R. D. G. P., Lepra. De maligne contagieuze Morbus Hansen en de benigne niet-contagieuze Hanseniden (Amsterdam: Van Holkema and Warendorf, 1948).

Simons, R. D. G. P., Lepra. De lepra-bestrijding in Suriname en de noodzakelijkheid harer reorganisatie (Amsterdam: Scheltema and Holkema, 1950).

Simons, R. D. G. P., Bijgeloof en lepra in de Atlantische Negerzônes (Paramaribo: Radhakishun, 1959).

Smidt, J. T. (ed.), Plakkaten, ordonnantiën en andere wetten, uitgevaardigd in Suriname 1667-1816 (Amsterdam: Emmering, 1973).

Stedman, J. G., Narrative of a Five Years' Expedition against the Revolted Negroes of Surinam, in Guiana on the Wild Coast of South America from the Years 1772 to 1777 (London: J. Johnson \& J. Edwards, 1796; repr. Amherst: University of Massachusetts Press, 1972).

Stern, I., Sternen-Saat (n.p.: Curitiba, 2010).

Surinaamsche Almanach, op het jaar onzer Heere Jesu Christi Anno 1789 (Paramaribo: W. H. Poppelman, 1789).

Teenstra, M. D., De landbouw in de kolonie Suriname (Groningen: Eekhoff, 1835).

Verslagen over de lepra te Suriname (Amsterdam: G. M. P. Landonck, 1851).

Veertig jaren Protestantsche Melaatschen verpleging "Bethesda" in Suriname (Paramaribo: Protestantsche Vereeniging, 1939).

Verheggen, A., God is liefde, Veertig jaren melaatschenverpleging 1895-1935 (Maastricht: Gebr. Van Aelst, 1935). 
Verslag der herdenking van het 25-jarig bestaan van "Bethesda" op 15 Mei 1924 (Paramaribo: Bethesda, 1924).

Veth, P. J., Java. Geographisch, ethnologisch, historisch, 2nd rev. ed., vol. 4 (Haarlem: De Erven Bohn, 1907).

Vijftig jaren Protestantse Melaatsen verpleging "Bethesda" in Suriname 18991949 (Paramaribo: Protestantsche Vereeniging, 1949).

Vinkhuijzen, De melaatschheid, vooral met betrekking tot hare oorzaken en verhouding in de maatschappij ('s-Gravenhage: De Gebroeders Van Cleef, 1868).

Virchow, R., Die krankhaften Geschwülste. Dreissig Vorlesungen, I (Berlin: August Hirschwald).

Weigel, M., Brieven uit Bethesda (Paramaribo: Nieuw-Bethesda, 1934).

Wesenhagen, A. C., Suriname, Iets over land en volk (Amsterdam: J. H. de Bussy, 1896).

Wolff, J. W., 'Het lepra-probleem in Suriname', Geneeskundig Tijdschrift voor Nederlandsch-Indië 65 (1925), pp. 572-87.

Woensel, P. van, 'West-Indische fragmenten', in A. Hanou (ed.), De lantaarn

(Amsterdam: Athenaeum-Polak \& Van Gennep, 2002).

Wolbers, J., Geschiedenis van Suriname (Amsterdam: De Hoogh, 1861).

Wright, H. P., Leprosy, an Imperial Danger (London: Churchill, 1889).

\section{Secondary sources, published books and articles}

Abbenhuis, M. F., 'De katholieke kerk in Suriname', Vox Guyanae 2 (1956), pp. 117-44.

Alveiz Moreira, T. M., and C. M. Varkevisser, Gender, Leprosy and Leprosy Control: A Case Study in Rio de Janeiro State, Brazil (Amsterdam: KIT, 1999).

Andel, T. van, 'The reinvention of household medicine by enslaved Africans in Suriname', Social History of Medicine 28 (2015), doi: 10.1093/shm/hkv014. Andel, T. van, and S. Ruysschaert, Medicinale en religieuze planten van Suriname (Amsterdam: KIT, 2011).

Andel, T. van, and S. Ruysschaert, 'What makes a plant magical? Symbolism and sacred herbs in Afro-Surinamese Winti rituals', in R. Voeks and J. Rashford (eds.), African Ethnobotany in the Americas (New York: Springer, 2011), pp. 247-84.

Anderson, W., 'Leprosy and citizenship', Positions 6 (1998), pp. 707-30.

Anderson, W., The Cultivation of Whiteness: Science, Health, and Racial Destiny in Australia (New York: Basic Books, 2003).

Anderson, W., Colonial Pathologies: American Tropical Medicine, Race and Hygiene in the Philippines (Durham, NC: Duke University Press, 2006). 
Arnold, D., 'Introduction: Disease, medicine and empire', in D. Arnold (ed.), Imperial Medicine and Indigenous Society (Manchester: Manchester University Press, 1988), pp. 1-26.

Arnold, D., Colonizing the Body: State Medicine and Epidemic Disease in Nineteenth-Century India (Delhi: Oxford University Press, 1993).

$\mathrm{Au}, \mathrm{S} .$, Mixed medicines: Health and Culture in French Colonial Cambodia (Chicago, IL: The University of Chicago Press, 2011).

Bankole, K., Slavery and Medicine: Enslavement and Medical Practices in Antebellum Louisiana (New York: Garland, 1998).

Bashford, A., Imperial Hygiene: A Critical History of Colonialism, Nationalism and Public Health (Basingstoke: Palgrave Macmillan, 2004).

Beeldsnijder, R. O., "“Om werk van jullie te hebben”. Plantageslaven in Suriname, 1730-1750' ( $\mathrm{PhD}$ thesis, Leiden University, 1994).

Bergen, L. van, and S. Snelders (eds.), 'Van piratendokters tot wetenschappelijke instituten. Drie eeuwen Nederlandse en Belgische tropische geneeskunde', Studium 2 (2009), pp. 53-129.

Berlin, I., and P. D. Morgan (eds.), The Slaves' Economy: Independent Production by Slaves in the Americas (London: Routledge, 1995).

Bewell, A., Romanticism and Colonial Disease (Baltimore, MD: The Johns Hopkins University Press, 1999).

Bhagwanbali, R., De nieuwe awatar van slavernij. Hindoestaanse migranten onder het indentured labour system naar Suriname, 1873-1916 (The Hague: Amrit, 2010).

Bijker, K., 'Power, prayer and colonial pacification: The Roman Catholic mission in nineteenth century Surinam', in M. Bax and A. Koster (eds.), Power and Prayer: Religious and Political Processes in Past and Present (Amsterdam: VU University Press, 1993), pp. 57-79.

Blom, A., 'Angst voor lepra', OSO 22 (2003), pp. 90-8.

Blom, A., 'Lepra in Suriname'. MensenBeelden 6 (2004), pp. 28-31.

Blom, J. C. H., and J. Talsma, De verzuiling voorbij. Godsdienst, stand en natie in de lange negentiende eeuw (Amsterdam: Het Spinhuis, 2000).

Boom, J., 'Het levensverhaal van Humbert Willems. Opstand in de leprozerie Groot-Chatillon', OSO 22 (2003), pp. 117-23.

Brouwers, J., Na de drie begijnen ging het verder. Geschiedenis van de Congregratie van de Zusters van Liefde van Onze Lieve Vrouw, Moeder van Barmhartigheid ('s-Hertogenbosch: Congregratie Zusters van Liefde, 2000), pp. 98-120.

Buckingham, J., 'The "morbid mark": The place of the leprosy sufferer in nineteenth century Hindu law', South Asia: Journal of South Asian Studies 20 (1997), pp. 57-80.

Buckingham, J., Leprosy in Colonial South India: Medicine and Confinement (Basingstoke: Palgrave, 2002). 
Buckingham, J., 'The inclusivity of exclusion: Isolation and community among leprosy-affected people in the South Pacific', Health and History 13 (2011), pp. 65-83.

Buddingh', H., De geschiedenis van Suriname (Amsterdam: Nieuw Amsterdam, 2012).

Burns, S. L., 'From "leper villages" to leprosaria: Public health, nationalism and the culture of exclusion in Japan', in C. Strange and A. Bashford (eds)., Isolation: Places and Practices of Exclusion (London: Routledge, 2003), pp. 104-18.

Cohen, R., Jews in Another Environment: Surinam in the Second Half of the Eighteenth Century (Leiden: E. J. Brill, 1991).

Cook, H. J., Matters of Exchange: Commerce, Medicine, and Science in the Dutch Golden Age (New Haven, CT: Yale University Press, 2007).

Crosby, Jr., A. W., The Columbian Exchange: Biological and Cultural Consequences of 1492 (Westport, CT: Greenwood, 1972).

Dankelman, J. L. F., Peerke Donders. Schering en inslag van zijn leven (Hilversum: Gooi en Sticht, 1982).

Davis, G., Holy Man: Father Damien of Molokai (Honolulu: University of Hawai'i Press, 1973).

Davis, N. Z., 'Physicians, healers, and their remedies in colonial Suriname', Canadian Bulletin of Medical History/Bulletin canadien d'histoire de la médecine 33 (2016), pp. 3-34.

Demaitre, L., Leprosy in Premodern Medicine: A Malady of the Whole Body (Baltimore, MD: The Johns Hopkins University Press, 2007).

Donselaar, J., van, Woordenboek van het Nederlands in Suriname van 1667 tot 1867 (Amsterdam: Meertens Insitituut, 2013).

Eckart, W. U., Medizin und Kolonialimperialismus: Deutschland 1884-1945 (Paderborn: Schöningh, 1997).

Edmond, R., Leprosy and Empire: A Medical and Cultural History (Cambridge: Cambridge University Press, 2006).

Eerenbeemt, A.J.J. M., De missie-actie in Nederland ( $\pm 1600-1940)$ (Nijmegen: J. J. Berkhout, 1946).

Einaar, J. F. E., Bijdrage tot de kennis van het Engelsch tussenbestuur van Suriname 1804-1816 (Leiden: M. Dubbeldeman, 1934).

Eyk, P. J. van, 'Oorlogsjaren in Suriname. Nederlands koloniaal beleid binnen Amerikaanse marges', OSO 14 (1995), pp. 148-57.

Farley, J., Bilharzia: A History of Imperial Tropical Medicine (Cambridge: Cambridge University Press, 1991).

Fermor, P. L., The Traveller's Tree: A Journey Through the Caribbean Islands (New York: New York Review Books, 2011).

Fett, S. M., Working Cures: Healing, Health, and Power on Southern Slave Plantations (Chapel Hill: The University of North Carolina Press, 2002). 
Foucault, M., Madness and Civilization: A History of Insanity in the Age of Reason (London: Routledge, 2001).

Fox-Genovese, E., and E. D. Genovese, The Mind of the Master Class: History and Faith in the Southern Slaveholders' Worldview (Cambridge: Cambridge University Press, 2005).

Garraway,D., The Libertine Colony: Creolization in theFrench Caribbean (Durham: Duke University Press, 2005).

Genovese, E. D., Roll, Jordan, Roll: The World the Slaves Made (New York: Pantheon, 1974).

Gómez Zuluaga, P. F., 'Bodies of Encounter: Health, Illness and Death in the Early Modern African-Spanish Caribbean' (PhD thesis, Vanderbilt University, 2010).

Gómez, P. F., 'The circulation of bodily knowledge in the seventeenth-century black Spanish Caribbean', Social History of Medicine 26 (2013), pp. 383-402.

Gould, T., Don't Fence Me In: Leprosy in Modern Times (London: Bloomsbury, 2005).

Govers, N., Leven van den eerbiedwaardigen Petrus Donders C.ss.R. Apostel der indianen en melaatsen in Suriname (Heerlen: Joh. Roosenboom, 1946).

Gussow, Z., Leprosy, Racism, and Public Health: Social Policy in Chronic Disease Control (Boulder, CO: Westview Press, 1989).

Hallewas, G.-J., 'De gezondheidszorg in Suriname' ( $\mathrm{PhD}$ thesis, Groningen University, 1981).

Handler, J., 'Diseases and medical disabilities of enslaved Barbadians, from the seventeenth century to around 1838', The Journal of Caribbean History, 40 (2006), pp. 1-38, 177-214.

Hardt, M., and T. Negri, Empire (Cambridge, MA: Harvard University Press, 2000).

Harrison, M., 'The tender frame of man: Disease, climate, and racial differences in India and the West Indies', Bulletin of the History of Medicine 70 (1996), pp. 68-93.

Harrison, M., Medicine in an Age of Commerce and Empire: Britain and Its Tropical Colonies 1660-1830 (Oxford: Oxford University Press, 2010).

Hassankhan, M. S., 'De immigratie en haar gevolgen voor de Surinaamse samenleving', in L. Gobardhan-Rambocus and M. S. Hassankhan (eds.), Immigratie en ontwikkeling. Emancipatieproces van contractanten (Paramaribo: Anton de Kom Universiteit, 1993), pp. 11-35.

Hassankhan, M. S., B. V. Lal, and D. Munro (eds.), Resistance and Indian Indentured Experience: Comparative Perspectives (New Delhi: Manohar, 2014).

Haynes, D. M., Imperial Medicine: Patrick Manson and the Conquest of Tropical Disease (Philadelphia, PA: University of Pennsylvania Press, 2001). 
Helmers, H., Een groot Nederlander in Suriname. Leven en werken van den eerbiedw. Dienaar Gods Petrus Donders (Tilburg: Henri Bergmans, 1946).

Hesselink, L., Healers on the Colonial Market: Native Doctors and Midwives in the Dutch East Indies (Leiden: KITLV Press, 2011).

Heuman, G., The Caribbean (London: Hodder Arnold, 2006).

Hinte-Rustwijk, D. van, and G. van Steenderen-Rustwijk, 'Van bedrijfsschade tot verzuilde paria, OSO 22 (2003), pp. 10-20.

Hoefte, R., De betovering verbroken. De migratie van Javanen naar Suriname en het rapport-Van Vleuten (1909) (Dordrecht: Foris, 1990).

Hoefte, R., In Place of Slavery: A Social History of British Indian and Javanese Laborers in Suriname (Gainesville, FL: University Press of Florida, 1998).

Hoefte, R., Suriname in the Long Twentieth Century: Domination, Contestation, Globalization (New York: Palgrave MacMillan, 2014).

Hoogbergen, W., and H. Ramsoedh (eds.), 'Lepra in Suriname', OSO, 22 (2003), pp. 1-123.

Hove, O. ten, '19e eeuws bevolkingsonderzoek naar lepra in Suriname', OSO 22 (2003), pp. 34-49.

Hulme, P., Colonial Encounters: Europe and the Native Caribbean, 1492-1797 (London: Methuen, 1986).

Hyam, R.,Empireand Sexuality: TheBritishExperience(Manchester:Manchester University Press, 1990).

Ingliss, K.I.,Disease and Displacement in Nineteenth-Century Hawai'I (Honolulu: University of Hawai'i Press, 2013).

Ismael, J., 'De immigratie van Indonesiërs in Suriname' ( $\mathrm{PhD}$ thesis, Leiden, 1949).

Jensen, N. T., For the Health of the Enslaved: Slaves, Medicine and Power in the Danish West Indies, 1803-1848 (Copenhagen: Museum Tusculaneum Press, 2012).

Kakar, S., 'Leprosy in India: The intervention of oral history', Oral History 23 (1995), pp. 37-45.

Kakar, S., 'Leprosyin British India, 1860-1940: Colonial politics and missionary medicine', Medical History 40 (1996), pp. 215-30.

Karbaat, J., '200 jaar militair hospitaal in Paramaribo (1760-1960)', Nederlands Militair Geneeskundig Tijdschrift 13 (1960), pp. 355-64.

Karbaat, J., 'Sociaal-geneeskundige beschouwingen over de personeelsleden van de troepenmacht in Suriname en hun gezinnen' (MD-thesis, Leiden University, 1963).

Karbaat, J., 'De historie van de militair-geneeskundige dienst in Suriname', Nederlands Militair Geneeskundig Tijdschrift 17 (1964), pp. 275-7.

Kerkhoff, A. H. M., 'The organization of the military and civil military service in the nineteenth century', in G. M. van Heteren. A. de Knecht-van Eekelen and 
M.J. D. Poulissen (eds.), Dutch Medicine in the Malay Archipelago 1816-1942 (Amsterdam: Rodopi, 1989), pp. 9-24.

Ketting, 'Bijdrage tot de geschiedenis van de lepra in Nederland' (MD-thesis, University of Amsterdam, 1922).

Ki Che Leung, A., Leprosy in China: A History (New York: Columbia University Press, 2008).

Kiple, K. F., The Caribbean Slave: A Biological History (Cambridge: Cambridge University Press, 1984).

Kiple, K. F., and Kriemhild Coneé Ornelas, 'Race, war and tropical medicine in the eighteenth-century Caribbean', in D. Arnold (ed.), Warm Climates and Western Medicine: The Emergence of Tropical Medicine, 1500-1900 (Amsterdam: Rodopi, 1996), pp. 65-79.

Kleijntjes, J., 'Mgr. Grooff, apostolisch vicaris van Batavia', Bijdragen voor de Geschiedenis van het Bisdom van Haarlem 47 (1931), pp. 373-468.

Kleinman, A., Patients and Healers in the Context of Culture: An Exploration of the Borderland between Anthropology, Medicine, and Psychiatry (Berkeley, CA: University of California Press, 1980).

Klerk, C. J. M., De immigratie van Hindoestanen in Suriname (Amsterdam: Urbi et Orbi, 1953).

Klinkers, E., 'De bannelingen van Batavia. Lepra-bestrijding gedurende de negentiende eeuw in koloniaal Suriname', OSO 22 (2003), pp. 50-61.

Klinkers, E., De geschiedenis van de politie in Suriname, 1863-1975. Van koloniale tot nationale ordehandhaving (Amsterdam: Boom, 2010).

Kronenburg, J. A. F., De eerbiedw, dienaar Gods Petrus Donders C.ss.R. Nieuwe levensbeschrijving (Tilburg: W. Bergmans, 1925).

Kuyp, E, van der, 'Surinaamse medische en paramedische kroniek 1494-1899', Surinaams Medisch Bulletin 9 (1985), pp. 1-67.

Kuyp, E. van der, 'De geschiedenis van lepra in Suriname tot 1971', Surinaams Medisch Bulletin 14 (1999), 1, pp. 43-64; 2, pp. 36-55.

Laguerre, M., Afro-Caribbean Folk Medicine (South Hadley, MA: Begrin \& Garvey, 1987).

Lamur, H. E., 'The Demographic Evolution of Surinam 1920-1970: A SocioDemographic Analysis' (PhD thesis, University of Amsterdam, 1973).

Laurence, B. R., “'Barbadoes leg”: Filariasis in Barbados, 1625-1900', Medical History 33 (1989), pp. 480-8.

Lenders, M., Strijders voor het lam. Leven en werk van Herrnhutter broeders en zusters in Suriname, 1735-1900 (Leiden: KITLV Press, 1996).

Lier, R. van, Frontier Society: A Social Analysis of the History of Surinam (The Hague: Martinus Nijhoff, 1971).

Lijphart, A., The Politics of Accommodation: Pluralism and Democracy in the Netherlands (Berkeley: University of California Press, 1975). 
Lindeboom, G. A. Dutch Medical Biography: A Biographical Dictionary of Dutch Pphysicians and Surgeons 1475-1975 (Amsterdam: Rodopi, 1984).

MacLeod, R., 'Introduction', in R. MacLeod and M. Lewis (eds.), Disease, Medicine, and Empire: Perspectives on Western Medicine and the Experience of European Expansion (London and New York: Routledge, 1988), pp. 1-18.

MacLeod, R. (ed.), 'Nature and empire: Science and the colonial enterprise', Osiris 15 (2000), pp. 1-317.

McCollin, D., 'Chacachacare: The island of lepers, 1922-1979', in C. Bonfield, J. Reinarz, and T. Huguet-Termes, Hospitals and Communities, 1100-1960 (Oxford: Peter Lang, 2013), pp. 263-90.

McNeill, J. R., Mosquito Empires: Ecology and War in the Greater Caribbean, 1629-1914 (Cambridge: Cambridge University Press, 2010).

Menke, H., interview with Paul Niemel, 'Lepra in Suriname: van segregratie naar integratie', OSO 22 (2003), pp. 21-33.

Menke, H., S. Snelders, and T. Pieters, 'Omgang met lepra in 'de West' in de negentiende eeuw. Tegendraadse maar betekenisvolle geluiden vanuit Suriname', Studium 2 (2009), pp. 65-77.

Mintz, S. W., and R. Price, The Birth of Afro-American Culture: An Anthropological Perspective (Boston, MA: Beacon Press, 1992).

Murto, C., C. Kaplan, L. Ariza, K. Schwarz, C. H. Alencar, L. M. M. da Costa, and J. Heukelbach, 'Factors associated with migration in individuals affected by leprosy, Maranhão, Brazil: An exploratory cross-sectional study', Journal of Tropical Medicine 2013: doi:10.1155/2013/495076.

Navon, L., 'Beggars, metaphors, and stigma: A missing link in the social history of leprosy', Social History of Medicine 11 (1998), pp. 89-106.

Obregon, D., 'Building national medicine: Leprosy and power in Colombia, 1870-1910', Social History of Medicine 15 (2002), pp. 89-108.

Oostindie, G., Roosenburg en Mon Bijou. Twee Surinaamse plantages, 17201870 (Dordrecht: Fortis, 1989).

Oudschans Dentz, F., 'De. Constantin Hering en Christiaan Johannes Hering', West-Indische Gids 12 (1931), pp. 147-60.

Oudschans Dentz, F., De kolonisatie van de Portugeesch Joodsche natie in Suriname en de geschiedenis van de Joden Savanne (Amsterdam: S. Emmering, 1975).

Pandya, S., 'The first international leprosy conference, Berlin 1897', Manguinhos 10, suppl. 1 (2003), pp. 161-77.

Panhuys, L. C. van, 'De Gouverneur-Generaal Willem Benjamin van Panhuys', De West-Indische Gids 6 (1925), pp. 291-320.

Peckham, R., and D. M. Pomfret (eds.), Imperial Contagions: Medicine, Hygiene, and Cultures of Planning in Asia (Hong Kong: Hong Kong University Press, 2013). 
Pluchon, P., Nègres et juifs au XVIIIe siècle. Le Racism au siècle des Lumières (Paris: Tallandier, 1984).

Postma, J., 'De leproserie Bethesda tussen 1897 en 1928', OSO 22 (2003), pp. 69-81.

Quinian, S., 'Colonial encounters: Colonial bodies, hygiene and abolitionist policies in eighteenth-century France', History Workshop Journal 42 (1996), pp. 107-26.

Ramsoedh, H., 'Suriname 1933-1944. Koloniale politiek en beleid onder gouverneur Kielstra' (PhD thesis, Utrecht University, 1990).

Ramsoedh, H., 'Rumcola en Yankeedollars', OSO 14 (1995), pp. 134-47.

Robertson, J., 'In a State of Corruption: Loathsome Disease and the Body Politic' (PhD thesis, University of Queensland, 1999), http://espace.library. uq.edu.au/view/UQ:193252/the13742.pdf. Accessed 21 October 2014.

Robertson, J., 'Leprosy and the elusive M. Leprae: Colonial and imperial medical exchanges in the nineteenth century', Manguinhos, 10; suppl.1 (2003), pp. $13-40$.

Robertson, J., 'The leprosy asylum in India, 1886-1947', Journal for the History of Medicine and Allied Sciences 64 (2009), pp. 474-517.

Rogozinski, J., A Brief History of the Caribbean: From the Arawak and the Carib to the Present (New York: Facts on File, 1999).

Rolander, D., 'Journal', in L. Hansen, D. Goodall, and J. Dobreff. (eds.), The Linnaeus Apostles: Global Science and Adventure, vol. 3, bd. 3 (London: IK Foundation, 2008), pp. 1217-564.

Savitt, T. L., Medicine and Slavery: The Diseases and Health Care of Blacks in Antebellum Virginia (Urbana, IL: University of Illinois Press, 1978).

Schalken, A. C., 'Historische gids bestaande uit chronologische lijst naamlijsten varia registers. 300 jaar R.K.-gemeente in Suriname 1683-1983’ (Paramaribo, n.p., 1985).

Schalkwijk, J. M. W., The Colonial State in the Caribbean: Structural Analysis and Changing Elite Networks in Suriname, 1650-1920 (The Hague: Amrit, 2011).

Schalkwijk, M., 'The plantation economy and the capitalist mode of production', in M. Schalkwijk and S. Small (eds.), New Perspectives on Slavery and Colonialism in the Caribbean (The Hague: Hamrit/Ninsee, 2012), pp. 14-40.

Schiebinger, L., 'The anatomy of difference: Race and sex in eighteenthcentury science', Eighteenth-Century Studies 23 (1989/1990), pp. 387-405.

Scholtens, B. P. C., Bosnegers en overhead in Suriname. De ontwikkeling van een politieke verhouding 1651-1992 (Paramaribo: Afdeling Cultuurstudies, 1994).

Scott, J. C., Domination and the Art of Resistance: Hidden Transcripts (New Haven, CT: Yale University Press, 1990). 
Scott, J. C., Seeing Like a State: How Certain Schemes to Improve The Human Condition Have Failed (New Haven, CT: Yale University Press, 1998).

Seng, L. K., Making and Unmaking the Asylum: Leprosy and Modernity in Singapore and Malaysia (Petaling jaya: Strategic Information and Research Development Centre, 2009).

Sheridan, R. B., Doctors and Slaves: A Medical and Demographic History of Slavery in the British West Indies, 1680-1834 (Cambridge: Cambridge University Press, 1985).

Smith Kipp, R., 'The evangelical uses of leprosy', Social Science and Medicine 39 (1994), pp. 165-78.

Snelders, S., “'Kapers van kennis”. De rol van een boekaniersgeleerde in de circulatie van kennis over ziekten en geneesmiddelen in de tropen', Studium 2 (2009), pp. 55-64.

Snelders, S., Vrijbuiters van de heelkunde. Op zoek naar medische kennis in de tropen 1600-1800 (Amsterdam: Atlas, 2012).

Snelders, S., 'Leprosy and slavery in Suriname: Godfried Schilling and the framing of a racial pathology in the eighteenth century', Social History of Medicine 26 (2013), pp. 432-50.

Snelders, S., and F. J. Meijman, De mondige patient. Historische kijk op een mythe (Amsterdam: Bert Bakker, 2009).

Spapens, P., Gwasi siki. Levensverhalen van Surinaamse mensen die lepra hebben gehad (Tilburg: Pix4Profs, 2012).

Stipriaan Luïscius, A. A. van, 'Surinaams contrast. Roofbouw en overleven in een Caraibische plantage-economie' (PhD thesis, Vrije University Amsterdam, 1991).

Stoler, A. L., Carnal Knowledge and Imperial Power: Race and the Intimate in Colonial Rule (Berkeley, CA: University of California Press, 2002).

Superlan, P., 'The Javanese in Surinam: Ethnicity in an Ethnically Plural Society' (PhD thesis, University of Illinois, 1978).

Themen-Sliggers, M., 'De maatschappelijke aspecten van lepra', OSO 22 (2003), pp. 104-11.

Thoden van Velzen, H. U. E., and W. Hoogbergen, Een zwarte vrijstaat in Suriname. De Okaanse samenleving in de achttiende eeuw (Leiden: KITLV Uitgeverij, 2011).

Thomas, K., Man and the Natural World: Changing Attitudes in England 1500-1800 (London: Allen Lane, 1983).

Trouillot, M.-R., Silencing the Past: Power and the Production of History (Boston, MA: Beacon Press, 1995).

Vaughan, M., Curing Their Ills: Colonial Power and African Illness (Cambridge: Polity Press, 1991). 
Veldhuyzen, W. F. H., Honderd en vijftig jaar pokken preventie (Amsterdam: Scheltema and Holkema, 1957).

Vernooij, J., 'Barmhartigheid een levensprogram. Zusters van liefde van Tilburg 100 jaar in Suriname' (Paramaribo, n.p., 1994).

Vernooij, J., De rooms-katholieke gemeente in Suriname. Handboek van de geschiedenis van de Rooms-Katholieke Kerk in Suriname (Paramaribo: Leo Victor, 1998).

Vernooij, J., 'Een opvallende relatie. De rooms-katholieke kerk en lepra in Suriname', OSO 22 (2003), pp. 62-8.

Vijftig jaren Hofbauer liefdewerk 1890-1940 (Rotterdam: Secretariaat der Surinaamsche Missie, 1940).

Vollset, M., 'Globalizing Leprosy: A Transnational History of Production and Circulation of Medical Knowledge 1850-1930' (PhD thesis, University of Oslo, 2013).

Waal Malefijt, A. H. de, 'The Javanese population of Surinam' ( $\mathrm{PhD}$ thesis, Colombia University, 1964).

Ward, J. R., British West Indian Slavery, 1750-1834 (Oxford: Clarendon Press, 1988).

Weaver, K. K., Medical Revolutionaries: The Enslaved Healers of EighteenthCentury Saint Domingue (Urbana, IL: University of Illinois Press, 2006).

Wekker, G., The Politics of Passion: Women's Sexual Culture in the Afro-Surinamese Diaspora (New York: Columbia University Press, 2006).

Wooding, C. J., 'Winti: Een Afroamerikaanse godsdienst in Suriname. Een cultureel-historische analyse van de religieuze verschijnselen in de Para' (PhD thesis, University of Amsterdam, 1972).

Worboys, M., 'The emergence of tropical medicine: A study in the establishment of a scientific specialty', in G. Lemaine, R. Macleod, M. Mulkay, and P. Weingart (eds.), Perspectives on the Emergence of Scientific Disciplines (The Hague: Mouton, 1976), pp. 75-98.

Worboys, M., 'Tropical diseases', in W.F. Bynum and R.Porter(eds.), Companion Encyclopedia of the History of Medicine, vol. 2 (London: Routledge, 1993), pp. 512-36.

Worboys, M., 'The colonial world as mission and mandate: Leprosy and empire, 1900-1940', Osiris 15 (2000), pp. 207-18.

\section{Secondary sources, unpublished manuscripts}

Bergen, L. van, 'De vreeselijkste van alle kwalen Lepra in Nederlands-Indië 1815-1942' (Royal Netherlands Institute of Southeast Asian and Caribbean Studies, Leiden, 2015). 
Menke, H. E., 'The Landré Family: Drama and Scientific Concept in a Slave Colony Ravaged by Leprosy' (Rotterdam, 2010).

Reyme, M., 'Give Ex-Leprosy Patients a Voice' (unpublished transcripts interviews, Anton de Kom Universiteit van Suriname, Paramaribo, 2013-2014).

Vernooij, J., 'De rooms-katholieke missie in Suriname ten tijde van Mgr. Grooff (1826-1853)' (Nijmegen, 1976).

Worboys, M., “An Imperial Danger": Leprosy and Contagion, 1860-1900' (University of Manchester, 2004). 